\title{
Mefloquine in the treatment of cutaneous leishmaniasis
}

\author{
Mefloquina no tratamento da leishmaniose cutânea
}

\author{
Dalmo Correia, Carlos Augusto de Campos Silva e Ângelo Gustavo Zucca Matthes
}

\begin{abstract}
Three cases of cutaneous leishmaniasis were treated orally with a mefloquine dose of $4.2 \mathrm{mg} / \mathrm{kg} /$ day for six days in the Teaching Hospital of the Faculdade de Medicina do Triângulo Mineiro, Uberaba, MG, Brazil. Three weeks later a new series was repeated. No patient was cured.
\end{abstract}

Key-words: Mefloquine. Treatment. Leishmaniasis.

Resumo Três casos de leishmaniose tegumentar em pacientes internados no Hospital Escola da Faculdade de Medicina do Triângulo Mineiro, Uberaba, MG, foram tratados com mefloquina, na dose de $4,2 \mathrm{mg} / \mathrm{kg} / \mathrm{dia}$ por via oral, durante seis dias. Nova série foi repetida três semanas após. Nenhum dos três pacientes foi curado.

Palavras-chaves: Mefloquina. Tratamento. Leishmaniose.

Gómez et $\mathrm{al}^{1}$ reported cure of patients with cutaneous leishmaniasis treated with mefloquine.

From August 1995 through March 1996, three patients were treated with mefloquine, in the Teaching Hospital of the Faculdade de Medicina do Triângulo Mineiro. In all these patients the diagnostic was confirmed by finding leishmanias in the smear test and through histopathology and Montenegro intradermal reaction. Mefloquine was administered in the dosage of $4.2 \mathrm{mg} / \mathrm{kg} /$ day by oral via, during six consecutive days. A new series was scheduled for after the third week of the treatment.

The medication was well tolerated. In the patients follow-up, one of them presented partial cicatrization of the lesion, thirty days after the end of the first series of the treatment. In the other two patients the lesions worsened after the second series of the medicament. Thus, they were treated with $\mathrm{N}$-metilglucamine antomoniate (Glucantime ${ }^{\circledR}$ ), in the dosage of $20 \mathrm{mg} / \mathrm{kg} /$ day, EV, during 20 days.

In view of the results obtained in the treatment of these three cases, as well as of the data obtained from five other individuals in the region of Corte de Pedra, Bahia State, Brazil (Mefloquine in the treatment of cutaneous leishmaniasis in an endemic area for Leishmania (Viannia) braziliensis, Revista da Sociedade Brasileira de Medicina Tropical, in print), we decided not treating with mefloquine other patients with cutaneous leishmaniasis.

\section{REFERENCE}

1. Gómez LE, Andrial M, Hosokawa A, Nonade S, Hashiguchi Y. Oral treatment of new world cutaneous leishmaniasis with mefloquine and artesunate in Ecuador: a preliminary clinical trial. Japanese Journal of Tropical Medicine and Hygiene 23:151-157, 1995.

Disciplina de Doenças Infecciosas e Parasitárias da Faculdade de Medicina do Triângulo Mineiro, Uberaba, MG, Brasil. Endereço para correspondência: Dr. Dalmo Correia. Disciplina de Doenças Infecciosas e Parasitárias/FMTM, Caixa Postal 118, 38001 970 Uberaba, MG, Brasil.

E-mail: dalmo@mednet.com.br

Recebido para publicação em 18/6/99. 